\title{
Large, oil-soaked endowment helps state universities weather current hard times
}

WITH the state of Texas looking at a $\$ 5,000$ million deficit this year, its higher education system is facing pressures familiar to university administrators in every other state. Texans want to support the University of Texas, says a spokesman, but invariably believe there is "fat to be trimmed". Recent talk of cutting costs by putting a limit on total enrolment, however, has alarmed taxpayers, who believe that if their money is paying for the university then their children should be able to attend it. On top of this, the university this year is facing a suit filed by the League of United Latin American Citizens and other civil rights groups who want the courts to direct a bigger fraction of education money to south Texas to redress alleged discrimination against Hispanic students.

But Texas has one thing that every other state would envy: the second largest higher education endowment in the nation, amounting to almost $\$ 3,500$ million. Only Harvard University has a bigger piggybank, but it does not have 15 widely scattered campuses and 150,000 students to support.

The endowment, two-thirds of which goes to the University of Texas (UT) and one-third to Texas A\&M University, derives from 2 million acres of arid scrub land in West Texas donated by the state in 1882 . Ashbel Smith, the first president of UT, said at a dedication in Austin about this unpromising real estate that one should "smite the rocks with the rod of knowledge, and fountains of wealth will gush forth". In 1923 , by drilling rather than smiting, oil gushed forth, and by the early 1980s UT was

that merely to maintain the buildings built during the boom may soon require capital to be drawn from the endowment.

To some extent this downturn has been offset by federal research dollars, which have risen from $\$ 273$ million in 1984 to $\$ 594$ million last year. This period coincides with the tenure of Hans Mark as chancellor of the university, a former official at the US National Aeronautics and Space Administration (NASA) with plenty of federal connections. The researchers brought to Texas by oil-money in earlier years now attract money of their own from Washington, so that in the past few years overall university income has held steady. The university as a whole, says one researcher at UT-Austin, is being treated "pretty much like the average state institution", and there are plenty of places in the country much worse off.

Mark is stepping down as chancellor this year, to teach in the engineering school at Austin, and will be replaced

receiving $\$ 200$ million a year from its 'worthless' land.

This money financed a grand expansion of the university, and turned the Austin campus into a notable research institution. But lower oil prices after the oil bust of the mid-1980s and dwindling reserves mean by William Cunningham, now president of the Austin campus and dean of business administration. His academic background is presumably good experience for maintaining the health of what is by the standards of the day a thriving university system.

David Lindley

\section{Academic research spending in 1991}

\section{Top Ten \\ (excluding medicine)}

Texas A\&M

U. of Texas at Austin

$U$. of Houston

Rice University

Texas Tech U.

$\mathrm{U}$. of Texas at Arlington

U. of North Texas

$\mathrm{U}$. of Texas at Dallas

U. of Texas at EI Paso

Southern Methodist $U$.
Figures in

$\$$ (millions)

243

208

38.4

30.1

22.8

12.5

12.3

10.5

9.6

8.2
Top medical schools

Baylor College of Medicine

UT MD Anderson Cancer Center, Houston

UT Southwestern Medical Center, Dallas

UT Health Science Center, Houston

UT Health Science Center, San Antonio

UT Medical Branch, Galveston

Texas Tech U. Health Sciences Center

UT Health Center, Tyler
Figures in $\$$ (millions)

152

108

94

54

45

38

6.6

5.0 